\title{
Biomonitoring of the Vltava River radioactivity
}

\author{
M. Svadlenkova and E.J. Hanslik ${ }^{1}$ \\ University of South Bohemia, Department of Physics, \\ Jeronymova 10, 37115 Ceské Budejovice, Czech Republic \\ ${ }^{1}$ T.G. Masaryk Water Research Institute, Department for Radioecology, \\ Podbabska 30, 16062 Prague 6, Czech Republic
}

\begin{abstract}
In 1996-2000, before the nuclear power plant starting in South Bohemia (Czech Rep.), the monitoring of the Vltava River, where the liquid radioactive effluents will be discharged, was accomplished. The biomonitoring of the hydrosphere was made by means of water plants and freshwater bivalve. Under given conditions, the water mosses Hygrohypnum ochraceum and Fontinalis antipyretica seem to be the most suitable plants. As to riverbank plants, Polygonum hydropiper species and the reed Glyceria maxima and Phalaris arundinacea were chosen. The freshwater bivalve Anodonta cygnea (L). Was also sampled. The ${ }^{137} \mathrm{Cs}$ mass activity values of the hydrobionts range from $10^{0}$ to $10^{1} \mathrm{~Bq} \cdot \mathrm{kg}^{-1}$ dry weight and its time course for the plants is descending: the ecological half-life estimations range from 1 to 5 years. As to natural radionuclides: ${ }^{40} \mathrm{~K}$ prove the highest values of mass activity (of the order of $10^{2} \mathrm{~Bq} \cdot \mathrm{kg}^{-1} \mathrm{~d}$. w.), while the radionuclides of actinium series prove the lowest ones (often under the detection limit). The radionuclides of uranium and thorium series are between these two extremities. The radioactivity of bivalve is low and practically constant during the five years period. The biomonitoring of the hydrosphere will be carried on after NPP running in 2001.
\end{abstract}

\section{INTRODUCTION}

The hydrosphere radioactive pollution monitoring made on purpose of the nuclear power plants fuel cycle impact assessment often tax the detection sensitivity of measuring instruments heavily, because of relatively low activity levels of the natural and man-made radionuclides. The suitable bioindicators, which highly accumulate certain radionuclides in their biomass, can by the indirect way facilitate the radionuclide identification and the water radioactivity determination compared to its direct measurement. Water plants are, due to their high ability to accumulate radionuclides and usual abundance in a sufficiently large amount, the suitable bioindicators of hydrosphere [1]. Their accumulation capacity depends above all on the radionuclide type and the plant species, but also on the radionuclide speciation, the vegetation period of plant, the activity concentration of water and its time course, the mineral composition, $\mathrm{pH}$, temperature and other water qualities, the period of plant contamination, and so on [2]. Bioaccumulation factor values related to dry weight are of order of magnitude ranging from $10^{1}$ to $10^{5}$. Abroad, water plants are already used as the bioindicators of radioactivity - for example in France for more than 25 years [3-5], but they would earn more attention, as the experience after the Chernobyl reactor accident has shown [6].

Freshwater bivalves are suitable especially for long-term bioindication of the presence of some man-made radioisotopes ( $\mathrm{Mn}, \mathrm{Sr}, \mathrm{Co}, \mathrm{Cs}, \mathrm{I}$, etc.) in hydrosphere [7].

\section{MATERIAL AND METHOD}

In the years 1996-2000, before the starting of PWR type nuclear power plant in Temelin (South Bohemia, Czech Rep.), the monitoring of the Vltava River, where the liquid radioactive effluents will be discharged, was accomplished ("point zero" determination) [8]. The biomonitoring of the hydrosphere was made by means of water plants and freshwater bivalve. 
Under given conditions, the water mosses Hygrohypnum ochraceum and Fontinalis antipyretica and also some green filamentous algae seem to be the most suitable submerged plants. The biomass of mosses is more abundant and their sampling is easier. As to riverbank plants, Polygonum hydropiper species and the reed Glyceria maxima and Phalaris arundinacea were chosen for sampling and analysis.

The low-level radioactive releases from nuclear power plant of Temelin will be discharged after it's running into the Vltava River at Kořensko locality. We took some samples at the reference locality above the Kořensko one and than at several localities below the Kořensko one, up to the capital Prague, where the water of Vltava River serves as a drinking water source.

The bivalve Anodonta cygnea $(L)$. Was also sampled from the valley reservoir of Vltava River.

After their sampling the hydrobionts were carefully washed in the river water, the shells and the soft tissue of the bivalves were separated, then the samples were dried at the $105^{\circ} \mathrm{C}$ to the constant weight, homogenised and measured. The measurement was made with help of the semiconductor gammaspectrometric device with the coaxial pure germanium detector and up to 16 thousand-channel analyser.

\section{RESULTS AND DISCUSSION}

The range of the ${ }^{137} \mathrm{Cs}$ mass activity values for different groups of hydrobionts during the period 19962000 are shown in the table 1 . This radionuclide is most accumulated by the algae and the mosses and. the least by the bivalves shells. The temporal trend of plant activity is decreasing as will be shown thereafter.

Table 1: The range of ${ }^{137} \mathrm{Cs}$ activities (Bq. $\mathrm{kg}^{-1}$ d.w.) for different groups of hydrobionts in years 1996-2000. The number of localities where the hydrobionts were sampled once a year is given in parenthesis.

\begin{tabular}{|l|c|c|c|c|c|}
\hline Hydrobiont I Year & 1996 & 1997 & 1998 & 1999 & 2000 \\
\hline aquatic mosses & $3.6-17.9(2)$ & $4.6-6.6(2)$ & $2.8-5.3(3)$ & $4.8-11.7(3)$ & $1.3-8.1(3)$ \\
\hline green algae & $7.7-21.8(2)$ & $6.1-7.6(3)$ & $5.8-10.4(2)$ & - & $4.0(1)$ \\
\hline riverbank plants & $3.5-9.3(4)$ & $1.3-9.8(7)$ & $1.3-5.5(7)$ & $0.8-6.4(6)$ & $<0.9-6.5(6)$ \\
\hline freshwater bivalve & $(1)$ & $(1)$ & $(1)$ & $(1)$ & $(1)$ \\
soft tissue & 1.5 & 1.4 & 2.9 & 2.8 & 1.4 \\
shells & 0.5 & 0.5 & 0.5 & 0.8 & 0.2 \\
\hline
\end{tabular}

The mean activity values of natural radionuclides in 1996-2000 for chosen mosses, algae and bivalve are shown at the table 2 . The significant differences can be seen for different hydrobionts and localities considering the point of nuclear power plant discharge. It can be also seen that the soft tissue of the bivalve Anodonta cygnea $(L)$ is not very suitable for the natural radionuclides biomonitoring.

The natural radionuclides activity of the riverbank plants was mostly under the detection limit of the used measuring apparatus.

The dispersion of activity values for individual species during the period 1996-2000 was in the wide range from 5 to $90 \%$. This must be taken into account when judging the impact of the nuclear power plant on the hydrosphere radioactivity.

The regression analysis of the ${ }^{137} \mathrm{Cs}$ mass activities of the hydrobionts denotes a decreasing trend during the years 1996-2000. The algae show the most decreasing trend whereas the riverbank plants the lowest one. The bivalve ${ }^{137} \mathrm{Cs}$ mass activity is nearly constant. The ecological halftime of water plant was derived on the basis of the regression analysis. The range of it is, for all analysed plant species, from 1 to 5 years with the mean value of 3.5 years. 
Table 2: The mean activities of chosen natural radionuclides (Bq. $\mathrm{kg}^{-1} \mathrm{~d} . \mathrm{w}$.) for some analysed hydrobionts; s. d.= standard deviation of the arithmetic mean values, NPP $=$ nuclear power plant, $*=$ above NPP future discharge, $* *=$ under NPP future discharge, $\mathrm{DL}=$ detection limit of the used measuring apparatus. The number of analysed samples is given in round bracket.

\begin{tabular}{|l|c|c|c|c|c|c|c|c|c|c|}
\hline $\begin{array}{c}\text { Hydrobionts } \\
\text { Radionuclide }\end{array}$ & Th-234 & s. d. & Ra-226 & s. d. & Ac-228 & s. d. & U-235 & s. d. & K-40 & s. d. \\
\hline Hygrohypnum ochr. (10) & 127 & 16 & 156 & 33 & 101 & 36 & 5.3 & 3.7 & 335 & 72 \\
\hline Fontinalis antipyretica (16) & 214 & 71 & 185 & 106 & 91 & 81 & 11.9 & 4.5 & 355 & 77 \\
\hline Algae $^{*}(6)$ & 111 & 35 & 148 & 101 & 118 & 30 & $<$ DL & - & 457 & 93 \\
\hline Algae $^{* *}(8)$ & 168 & 40 & 75 & 40 & 43 & 14 & $<$ DL & - & 326 & 58 \\
\hline Anodonta cygnea-soft (20) & 91 & 66 & 75 & 58 & 34 & 20 & 11.8 & $\begin{array}{c}\text { One } \\
\text { value }\end{array}$ & 168 & 80 \\
\hline Anodonta cygnea-shells (20) & <DL & - & 9.7 & 6.1 & 3.4 & 0.7 & $<$ DL & - & 18 & 12 \\
\hline
\end{tabular}

\section{CONCLUSION}

The application of the water plants and the bivalve for the biomonitoring of the hydrosphere radioactivity was briefly demonstrated in this contribution. Under given conditions of Vltava River the most suitable for this purpose are the submerged plants, especially the water mosses.

The biomonitoring of the hydrosphere will be carried on after the NPP running in 2001.

\section{Acknowledgements}

This study was partly financed by the Czech Ministry of the Environment and the Czech Energy Company in frame of the project on the impact of the Czech nuclear power plant of Temelin on the environment.

\section{References}

[1] Pally. M., Foulquier. L., La capacité et les modalités de la fixation du radiocesium par les végétaux aquatiques. Bibliographie CEA-BIB-235 (1981) C20, Paris, CE Cadarache, 255 pp.

[2] Švadlenková. M., Dvořák. Z., Slávik. O., Int. Rev.Gesamten Hydrobiologie, 74 (1989): $461-469$.

[3] Foulquier. L., Hebrard. J.P., Oecol. Plant., 11 (1976): 259-276.

[4] Vray. F., Baudin. J.P., Švadlenková.M., Arch. Environ. Contam. Toxicol. 23 (1992): 190-197.

[5] Beaugelin-Seiller. K., Caractérisation de mousses dulçaquicoles comme indicateurs de contamination radioactive. Rapport CEA-R-5697, (1995) IPSN, CE Cadarache, France.

[6] Foulquier. L., Baudin-Jaulent. Y., Impact Radioécologique de l'Accident de Tchernobyl sur les Ecosystemes Aquatiques. CEC - Radiation protection 58, (1992) UIR. No. 90-ET-014.

[7] Vanderploeg. H.A. et al. Bioaccumulation Factors for Radionuclides in Freshwater Biota. Oak Ridge Nat. Lab., Environ. Sci. Div. Public. No. 783 (1975), ORNL-5002, 222 pp.

[8] Hanslík. E. et al., The research on the impact of the nuclear power plant of Temelín on the hydrosphere. Report No. 0081, (1995) Research Inst. of Water Management T.G.Masaryk, Prague. 169 pp. (in Czech) 